\title{
Kwestia polska a misja Rosji wśród Słowian
}

W pierwszej połowie XIX w. idea solidarności słowiańskiej stała się trwałym elementem ideologicznego i politycznego bytu wszystkich narodów słowiańskich pozbawionych własnej państwowości. Ideę tę rozumiano $z$ jednej strony jako świadomość wspólnej historycznej przeszłości, w tym językowej, kulturowej i po części religijnej bliskości Słowian jako całości, $z$ drugiej zaś jako potrzebę wzajemnego wspierania rozwoju oryginalnych języków i kultury narodów słowiańskich. Idea ta przeistoczyła się w istotny element formujących się ideologii narodowych, a jej głównym celem było wsparcie działań podejmowanych przez te narody w celu osiagnięcia równouprawnienia, a w dalszej perspektywie także niepodległości.

Idea wszechsłowiańska zaczęła zdobywać popularność również $\mathrm{w}$ społeczeństwie rosyjskim, lecz otrzymała w nim specyficzna interpretację ${ }^{1}$. $Z$ powodu odmiennych warunków politycznych, w których znajdowała się Rosja, pośród jej społeczeństwa utrwaliło się przekonanie, że właśnie Rosji i narodowi rosyjskiemu należy się wiodąca rola w procesie odrodzenia słowiańskiego. Jednakże rosyjskie próby zaakceptowania idei „wspólnoty słowiańskiej” i wzięcia na siebie roli protektora i inicjatora działań Słowian od początku napotkały na poważne przeszkody: dla Rosji „kwestia słowiańska” była zarówno problemem $z$ zakresu polityki międzynarodowej, jak i sprawą wewnątrzpaństwową. W granicach imperium Wielkorusini współżyli bowiem $z$ innymi narodami słowiańskimi. Przyjęcie idei „solidarności słowiańskiej” oznaczałoby wsparcie dążeń tych narodów do językowej, kulturowej, a w przyszłości także politycznej

* Wydział Historyczny, Katedra Historii Nowożytnej i Współczesnej.

1 T. G e o r gi e va, Slavjanskata ideja $v$ Rusija 30-te - 50-te godini na XIX v., Sofija 2009. 
emancypacji. Poparcie dla ruchów narodowościowych bałkańskich $i$ austriackich Słowian było dla Rosji równoznaczne $z$ uznaniem tych samych praw dla Słowian w swoim państwie, a w owym czasie władza w Petersburgu nie była skłonna do pójścia na kompromis $\mathrm{w}$ kwestii podobnych ruchów w carstwie. O ile w pierwszej połowie wieku XIX ukraiński ruch narodowościowy był jeszcze bardzo słaby, a białoruski znajdował się w początkowym stadium swojego rozwoju, to głównym problemem Rosji i jej misji wśród Słowian była Polska.

Społeczeństwo rosyjskie było więc rozdarte między naturalnym dążeniem do wsparcia pokrewnych mu narodów w ich staraniach o samodzielny rozwój narodowościowy a niechęcią do uznania ich praw do podobnego rozwoju w ramach własnego państwa. Dodatkowym problemem stało się to, że popularyzacja „kwestii słowiańskiej" w północnym imperium zbiegła się z nowym kryzysem w relacjach rosyjsko-polskich. Powstanie przeciwko władzy rosyjskiej, które wybuchło w Królestwie Polskim w 1830 r., stało się przyczyna radykalnej zmiany $\mathrm{w}$ oficjalnym kierunku polityki Petersburga względem Polski: autonomiczne rządy Polaków, wprowadzone przez Aleksandra I, zostały zlikwidowane, unieważniono konstytucję, a narzucony przez Iwana Fiodorowicza Paskiewicza reżim zakładał walkę $z$ przejawami polskich dążeń narodowościowych i wzmożoną rusyfikację regionu ${ }^{2}$. To wszystko dodatkowo utrudniało wszelka próbę sformułowania w Rosji jasnej i kategorycznej postawy wsparcia dla idei wszechsłowiańskiej, jak również prób kreowania Rosji, lub narodu rosyjskiego, na obrońcę i opiekuna słowiańskich ruchów narodowych.

Widać to przede wszystkim w stanowisku oficjalnej władzy. Mikołaj I, car rosyjski, wielokrotnie wyrażał swój negatywny stosunek wobec ruchów narodowościowych Słowian w Cesarstwie Austriackim i niechęć do jawnego wmieszania się w związane $z$ nimi kwestie. Tę samą zdystansowana politykę realizował w odniesieniu do narodowych ruchów Słowian w Imperium Osmańskim³ ${ }^{3}$. Tradycyjnie

2 Zapadnye okrainy Rossijskoj imperii, Moskwa 2006.

3 Mikołaj I przyjał co prawda zasadę obrony wiary prawosławnej i społeczności chrześcijańskich w relacjach dyplomatycznych $z$ Porta, zakładając jednocześnie konieczność utrzymania ich w poddaństwie wobec sułtana. Rosja tradycyjnie uciekała się do wykorzystywania oddziałów zbrojnych, złożonych z ludności bałkańskiej, w swoich wojnach $z$ Imperium Osmańskim, lecz rozpatrywała tę praktykę jedynie jako środek służący wywarciu dodatkowej presji na przeciwniku jako 
tę postawę władz rosyjskich tłumaczy się powiązaniami Petersburga $z$ zalegalizowanymi reżimami w Europie. $Z$ tego punktu widzenia nacjonalistyczne pretensje narodów słowiańskich rozpatrywano jako zamach przeciwko prawowitej władzy i część ruchu rewolucyjnego, który objął cała Europę. Nie mniej ważne było również to, że wystapienia przeciwko władzy w sasiednich krajach niosły ze sobą realne niebezpieczeństwo ich przeniesienia się na terytorium Rosji, także na pograniczne tereny polskie. Obawa przed nowym polskim buntem kierowała Mikołajem I w jego postawie wobec wydarzeń $z$ lat 1848-1849. Rosja zaingerowała w niepokoje na terenie Austrii w momencie, gdy „wewnętrzny ruch austriacki zaczą przybierać polskie barwy"4. Car rosyjski uważał Polaków za głównych prowodyrów niepokojów w Cesarstwie Austriackim i to przekonanie wpłynęło na jego skrajnie negatywny stosunek do tamtejszych wydarzeń, także wobec zwołanego w Pradze Zjazdu Słowiańskiego. $\mathrm{W}$ tym również tkwiła przyczyna jego zaangażowania $\mathrm{w}$ zdławienie rewolucji węgierskiej - monarcha widział w niej „wysiłki zmierzające do powszechnej zmowy przeciwko wszystkiemu, co święte, w szczególności przeciwko Rosji, gdyż na czele buntu stoją i jego głównymi prowodyrami sa nasi odwieczni wrogowie, Polacy"5.

Bardziej bezpośrednią przyczyną wstrzemięźliwości władz rosyjskich względem idei wszechsłowiańskiej była jednak obawa, że ewentualne pozytywne gesty Petersburga względem Słowian $z$ innych państw mogłyby dać dodatkowy impuls polskiemu ruchowi niepodległościowemu. Walka $z$ narodowościa polska stanowiła jedna $z$ charakterystycznych cech polityki rosyjskiej za panowania Mikołaja I. Hrabia Karl Nesselrode, który stał na czele rosyjskiej dyplomacji przez prawie 40 lat, określił prowadzona przez cara polityke jako „monarchistyczna i antypolska”"6. Z cała mocą stwierdzenie to odnosiło się również do wewnątrzpaństwowej polityki Petersburga.

„korzystna dywersję”, a nie wspieranie dążeń wyzwoleńczych zniewolonych narodów - Pis'mo imperatora Nikolaja M.D. Gorczakowu (1 fewral’ 1854 g.), „Russkaja Starina" 1876, R. VII, t. XVII, nr 10, s. 357.

4 S.M. S ołowjow, Rossija, Awstrija i Anglija wo wremija dwiżenija 18481849 gg., „Russkaja Starina” 1877, R. VIII, t. XX, nr 11, s. 423.

5 List cara Mikołaja I z 8/20 kwietnia 1849 r. - A. Szterbatow, General fel'dmarszal knjaz Paskiewicz. Ego żizn' $i$ dejatel'nost', t. VII, Sankt-Peterburg 1907, s. 282-284.

6 Zapiska grafa K.W. Nesel'rode „O politiczeskich snoszenijach Rossii”, „Russkij Archiw” 1872, R. X, nr 1, s. 341. 
Antypolski kierunek polityki rosyjskiej stawiał Petersburg w dwuznacznej pozycji względem całej Słowiańszczyzny, nie pozwalając mu na zajęcie jasnego i kategorycznego stanowiska wobec jej odrodzenia narodowego oraz wyciągnięcia $z$ niego korzyści na arenie międzynarodowej. Realizowana przez rząd rosyjski od $1830 \mathrm{r}$. linia odrzucania narodowościowych żądań Polski i tłumienia jej walki o niezawisłość państwową uniemożliwiały okazanie przez niego wsparcia pozostałym narodom słowiańskim w ich dążeniach do niezawisłości. Poparcie takie bowiem nieodzownie wywołałoby problem przewartościowania carskiej polityki wobec Polski - czyli kwestii, której zwyczajowo nie podnoszono w stolicy rosyjskiej. $Z$ drugiej strony rosyjskie poparcie dla dążeń narodowościowych Słowian dałoby Polakom podstawę do wysunięcia wobec imperium żądania, by spełniono ich pretensje narodowe.

Dwuznaczna pozycja, w której znalazła się Rosja wobec Polski i narodów słowiańskich, zmusiła Mikołaja I do zdecydowanego zdystansowania się wobec słowiańskich dążeń narodowościowych i uczyniła go szczególnie ostrożnym wobec jakichkolwiek inicjatyw dotyczących Słowiańszczyzny. Polska pozostała „kamieniem potknięcia" dla słowiańskiej misji Rosji także za czasów kolejnego panowania: w końcu lat pięćdziesiątych XIX w. W środowisku rzadzących zrodził się pomysł wydawania gazety, która podsycałaby sympatie narodów słowiańskich wobec Rosji. Idea ta nie została zrealizowana przede wszystkim ze względu na obawy o wpływ, jaki podobna publikacja miałaby na Polaków. W tej kwestii Michaił Dymitrowicz Gorczakow, ówczesny namiestnik Królestwa Polskiego, przestrzegał cara Aleksandra II, że dążenie do podtrzymywania przywiazania narodów słowiańskich do Rosji przez podsycanie w nich uczuć narodowościowych jest pożyteczne i godne pochwały, gdy chodzi o ludy znajdujące się pod panowaniem Turcji, lecz nie jest całkiem bezpieczne w odniesieniu do Polski. Myśl o niezależnym funkcjonowaniu ich narodowości będzie miała wśród Polaków skutek przeciwny do zamierzonego: będzie im przypominać o utraconej państwowości i zamiast rozwijać sympatię do Rosji, zwróci ich przeciwko tej ostatniej - twierdził Gorczakow7.

Twierdzenia o solidarności słowiańskiej nie zyskały w Petersburgu dużej popularności w pierwszej połowie XIX w. także dlate-

7 N.P. B a r s ukow, Żizn' $i$ trudy Michaila Pogodina, t. XVI, Sankt-Peterburg 1902, s. 424-427. 
go, że władze rosyjskie widziały w nich oddźwięk i wpływ polskich idei nacjonalistycznych, a w walce o samookreślenie się narodów słowiańskich - rękę polskiego ruchu wyzwoleńczego. Rzeczywiście w tym okresie idea jedności słowiańskiej dopiero zaczynała zdobywać zwolenników w społeczeństwie rosyjskim, podczas gdy była już mocno zakorzeniona pośród części przedstawicieli polskiego ruchu narodowego, w środowisku, w którym zrodziła się również myśl rozwiązania kwestii polskiej w ramach problemu ogólnosłowiańskiego. Na podejrzliwość rosyjskich rządzacych wobec idei solidarności słowiańskiej niewątpliwie wpłynął bunt $z$ grudnia 1825 r. ${ }^{8}$ Dowiedzione kontakty Towarzystwa Południowego dekabrystów $z$ polskim ruchem narodowym, udział w spisku dekabrystów Stowarzyszenia Zjednoczonych Słowian, którego celem było stworzenie demokratycznej federacji narodów słowiańskich, jak również członkostwo Polaków w tej ostatniej organizacji wzmacniały przekonanie Petersburga co do zasadności ciagu powiązań „idea wszechsłowiańska - Polacy - rewolucja”. Właśnie po nieudanym przewrocie $z 1825$ r. zmienił się oficjalny stosunek Rosji do idei słowiańskiej. Problematyka słowiańska straciła wówczas swój ściśle akademicki charakter i zaczęła być postrzegana jako zagadnienie politycznie zaangażowane, bez względu na to, czy chodziło o kontakty kulturalne, naukowe czy też religijne.

Władze rosyjskie nie postrzegały idei wszechsłowiańskiej jako zwykłego przekonania o charakterze rewolucyjnym, lecz jako pogląd, który polscy działacze narodowościowi rozpowszechniali w celu osiagnięcia swojego ostatecznego celu - odzyskania niepodległego państwa polskiego. Petersburg był przekonany, że pogląd ten stanowił środek, który polski ruch narodowościowy starał się wykorzystać w walce $z$ władza carska. Dowodza tego materiały ze śledztwa w sprawie Bractwa Cyrylo-Metodejskiego, pochodzace z 1847 r. Dokumenty Trzeciego Oddziału Kancelarii Osobistej Jego Cesarskiej Mości, czyli policji politycznej za rządów Mikołaja I, jednoznacznie potwierdzają, że władze uznawały ideę jedności słowiańskiej za prowokację ze strony emigracji polskiej, której celem było naruszenie integralności Rosji. W materiałach tych walka o jedność Słowian przedstawiona została jako szeroko zakrojony spisek, u podstaw którego stali Polacy $z$ ich dążeniem do odzyska-

8 M. N e c z ki n a, Obszestwo soedinennych slawjan, Moskwa-Leningrad 1927, s. 91. 
nia niepodległości. Spisek, którego celem było wzniecenie powszechnej rewolty narodów słowiańskich. W raporcie Trzeciego Oddziału $z$ kwietnia 1847 r. stwierdzono, że polscy emigranci podżegają plemiona słowiańskie tylko dlatego, że maja nadzieję, iż w ten sposób osiągną swój „ułudny i nędzny” cel - restytucję niezawisłego państwa polskiego ${ }^{9}$. Aleksiej Fiodorowicz Orłow, naczelnik Trzeciego Oddziału, napisał w tej sprawie do cara, że „mając za jedyny cel przywrócenie dawnej Polski i wyłącznie $z$ tego powodu zburzenie spokoju czterech mocarstw, którym podlegają Słowianie, Polacy podżegaja te plemiona i je pobudzaja do przywrócenia w każdym $z$ nich ich dawnego, patriarchalnego sposobu życia"10.

Nie będzie więc przesada twierdzenie, że powiąanie kwestii polskiej $z$ idea wszechsłowiańską stanowi jedną $z$ głównych przyczyn zdystansowania się oficjalnej polityki rosyjskiej od słowiańskiego ruch narodowego. Przez długi okres Petersburg widział w idei wspólnoty słowiańskiej przede wszystkim „polska intrygę" (podobnie w latach sześćdziesiątych XIX w. Michaił Nikiforowicz Katkow postrzegał ukrainofilizm jako „intryge polska”).

„Kwestia polska” wpłynęła również na interpretację idei wspólnoty wszystkich Słowian przez rosyjską elitę rządząca, mianowicie, że to Rosja jest nosicielem najbardziej autentycznej istoty słowiańskości i stanowi uosobienie narodowości słowiańskiej, a przyszłość Słowiańszczyzny należy wiązać tylko i wyłącznie $z$ nią. $Z$ dwóch powodów minister oświaty, hrabia Siergiej Siemionowicz Uwarow uczynił $z$ tematyki słowiańskiej integralna część imperialnej doktryny Rosji. $Z$ jednej strony chciał dowieść, że historyczna misja, którą Rosja będzie realizowała w odniesieniu do Słowiańszczyzny, jest pochodna absolutyzmu i istniejącego ładu społeczno-politycznego. $Z$ drugiej zaś włączenie tematyki słowiańskiej do doktryny carskiej zwiazane było $z$ polityka realizowana przez imperium $\mathrm{w}$ Polsce i guberniach zachodnich. Uwarow sądził, że polityczne scalenie poszczególnych części państwa musi być poprzedzone ich zjednoczeniem moralnym i intelektualnym. Przekonany był, że pokojowa integracja narodów zamieszkujących cesarstwo możliwa jest dzięki edukacji. W tym celu, według niego, w nierosyjskiej ludności należy „złamać niemieckiego bądź polskiego ducha" i jako przeciwwagę wobec nich rozwinąc rosyjskie poczucie

9 Kirilo-Mefodiiws'ke towaristwo, t. I, Kiiw 1990, s. 38-39.

10 Ibidem, t. III, s. 306. 
narodowe, które stanie się ostoja istnienia państwa i podstawa moralności11. W związku $z$ tym kładł duży nacisk na wiedzę zdobywaną $\mathrm{w}$ szkołach. Liczył na popularyzację języka rosyjskiego w guberniach zachodnich, zamieszkałych przede wszystkim przez Ukraińców, Białorusinów i Litwinów. Miał nadzieję, że otwarty w 1833 r. w Kijowie Uniwersytet „św. Włodzimierza” będzie krzewić kulturę rosyjska i w ten sposób „wygładzać specyficzne cechy charakteru, które tak wyraźnie odróżniają młodzież polską od rosyjskiej, w szczególności zagłuszać w niej myśl o odrębnej narodowości, która zrodziła próżne dążenia do odbudowy $z$ dawna utraconej niezależności"12.

W Polsce, kraju o bogatej kulturze i rozwiniętym poczuciu narodowym, realizacja asymilacji kulturowej była nie do zaakceptowania. $Z$ tego powodu w stosunku do ziem czysto polskich Uwarow szukał bardziej umiarkowanego, pośredniego podejścia, unikającego gwałtownej zamiany języka polskiego na rosyjski oraz skrajnej polityki rusyfikacyjnej. Istnieją podstawy, by sądzić, że włączenie tematyki słowiańskiej w politykę edukacyjną Uwarowa było częścia tej pojednawczej, pozbawionej skrajności drogi przeprowadzenia asymilacyjnej w swej istocie polityki względem Polski. Od lat czterdziestych XIX w. podjęto wysiłek nauczania języków słowiańskich w szkołach na terytorium byłego Królestwa Polskiego - w instytucjach edukacyjnych Warszawskiego Okręgu Naukowego ${ }^{13}$. Po 1841 r. nauczycielami języka rosyjskiego $\mathrm{w}$ gimnazjach i szkołach średnich mogli zostać jedynie kandydaci mogacy $z$ powodzeniem nauczać także innego języka słowiańskiego. Natomiast pensjonariusze $z$ Królestwa Polskiego, kształcący się na uniwersytetach rosyjskich, zobowiązani byli do uczęszczania na wykłady $z$ języka słowiańskiego i zdawania $z$ niego egzaminu i pilnie śledzono ich postępy $w$ tej dziedzinie ${ }^{14}$. Najwyraźniej nauczanie dodatkowego języka słowiańskiego rozpatrywane było jako środek służący zminimalizowaniu

11 Desjatiletije Ministerstwa narodnogo prosweszczenija 1833-1843. Zapiska predostawlennja Gosudarju Imperatoru Nikolaju I Ministrom narodnogo prosweszczenija grafom Uwarowym w 1843 g., Sankt-Peterburg 1864, s. 36, 136-137.

12 Obszczij otczet ob. osmotre Uniwersiteta „Sw. Wladimira” - Desjatiletie MNP, s. 68-69.

13 S.W. Ro ż d e s tw e n s ki, Istoriczeskij obzor dejatel'nosti Ministerstwa narodnogo prosweszczenija 1802-1902 gg., Sankt-Peterburg 1902, s. 315; Obszczij otczet MNP za 1840 g., „Żurnal Ministerstwa Narodnogo Prosweszczenija” 1841, nr 30, s. 17-136.

14 Desjatiletije Ministerstwa..., s. 64. 
przytłaczajacej dominacji polszczyzny $z$ jednoczesnym wystrzeganiem się przed gwałtowną zamiana tej ostatniej przez rosyjski. $Z$ drugiej strony nauczanie kultury i języków słowiańskich, połączone $z$ przedstawianiem Rosji jako najważniejszego ośrodka Słowiańszczyzny, z podkreślaniem jej wyższości nad pozostałymi Słowianami, miało pomóc w zbliżeniu Polaków i Rosjan i złączeniu się ich w jedną całość. Miało to osłabić „fałszywy” patriotyzm Polaków i służyć jako przeciwdziałanie świadomości narodowej i nacjonalizmowi polskiemu.

Realizowana przez Uwarowa polityka wykorzystywania idei wszechsłowiańskiej do celów wewnątrzpaństwowych została poważnie zdyskredytowana ujawnieniem w 1847 r. istnienia Bractwa Cyrylo-Metodejskiego ${ }^{15}$. Powstanie organizacji łączącej ideę panslawistyczna $z$ walka o niezawisłość polityczna ukazało, jak ryzykowna dla władz rosyjskich była zagrywka $z$ kwestią słowiańską. Przypadek ten zmusił rosyjskich rządzących do wyciagnięcia wniosku, że „tylko jeden krok dzieli naukową slawistykę, zainteresowanie lokalnym kolorytem, od rewolucyjnego panslawizmu oraz nacjonalistycznego separatyzmu"16. Z kolei rewolucje $z$ lat 1848-1849 ostatecznie przekonały Petersburg do wyłączenia idei wspólnoty słowiańskiej ze swego arsenału ideologicznego.

Społeczeństwo rosyjskie doskonale zdawało sobie sprawę ze sprzeczności między interesami państwa w Polsce a pragnieniem ukazywania północnego imperium jako obrońcy narodów słowiańskich. W swoim dzienniku, stanowiącym jedno $z$ najcenniejszych źródeł do epoki Mikołaja I, profesor Aleksander Wasiljewicz Nikitienko wskazał odrodzenie narodowości jako jedno $z$ naczelnych zadań swoich czasów, przyznając jednocześnie, że odłączenie Słowian od Cesarstwa Austrii podniesie kwestię polska. Nikitienko pytał więc: „Słowianofile marza o federacji słowiańskiej. Jaka rolę będzie wówczas w niej odgrywała Rosja? Czy dobrowolnie zrezygnujemy z Polski?"17.

15 Była to tajna organizacja założona w Kijowie przez grupę patriotów ukraińskich. Jako swój cel ogłosiła stworzenie wszechsłowiańskiego związku federacyjnego $z$ głównym ośrodkiem w Kijowie, w ramach którego funkcjonowałoby także niezawisłe państwo ukraińskie. Stanowiła jeden $z$ pierwszych wyraźnych przejawów ukraińskiego ruchu nacjonalistycznego.

16 S. Wit te ke r, Graf Siergiej Siemanowicz Uwarow i ego wremija, Sankt-Peterburg 1991, s. 246-247.

17 A.W. Nikite n k o, Dnewnik (1804-1877), Sankt-Peterburg 1904, s. 561. 
Najjaskrawiej powyższy problem stał przed tymi przedstawicielami wykształconej elity rosyjskiej, którzy wspierali pogląd o historycznej misji Rosji wśród narodów słowiańskich. W tej kwestii szczególnie interesujące były poglądy takiej osobistości, jak Michaił Pietrowicz Pogodin, wzywający do zmiany rosyjskiej polityki zagranicznej i pogłębienia związków Rosji z narodami słowiańskimi kosztem relacji $z$ Wiedniem i Berlinem. Pogodin, historyk i publicysta, był pierwszym i najbardziej gorliwym zwolennikiem idei solidarności słowiańskiej w cesarstwie $\mathrm{w}$ pierwszej połowie stulecia i uczynił wiele dla jej popularyzacji w społeczeństwie, nieskromnie określając siebie jako alfę i omegę idei słowiańskiej w Rosji18.

Ewolucja, która przechodziły jego poglądy odnośnie do miejsca i roli Rosji w odrodzeniu słowiańskim, w znacznym stopniu wynikała $z$ chęci połączenia dwóch trudno dajacych się pogodzić kwestii - misji Rosji wśród Słowian i utrzymania rosyjskiej dominacji nad Polska. Problemem było to, że niewielu ludzi w Rosji uznawało prawa narodu polskiego do posiadania własnego państwa. Dla przeważającej części społeczeństwa rosyjskiego przyszłość włączonego do cesarstwa w 1815 r. Królestwa Polskiego, jak również terytoriów przyłączonych do Rosji w wyniku trzech rozbiorów Polski w końcu XVIII w. były nie do pojęcia poza granicami imperium. Zanim jednak zaakceptował ideę słowiańskiej misji swojej ojczyzny, Pogodin stał na stanowisku, które nie różniło się od oficjalnej tezy władzy carskiej. Wyraził ja w artykule napisanym wkrótce po powstaniu z 1830 r.: w wyniku trzech rozbiorów Polski Rosja odzyskała ziemie, które jej się należały zgodnie $z$ prawem; miejsce Polski jest w Rosji i oddzielenie jej od cesarstwa nie jest już możliwe ${ }^{19}$.

Podróże rosyjskiego historyka po ziemiach słowiańskich Cesarstwa Austriackiego w końcu lat trzydziestych i na początku lat czterdziestych XIX stulecia uświadomily mu sprzeczność między powyższa tezą a próbami przedstawiania Rosji w roli przewodnika słowiańskiego ruchu narodowościowego. Podczas swoich licznych kontaktów $z$ przedstawicielami inteligencji zachodniosłowiańskiej Pogodin zderzył się $z$ ich krytyka polityki Rosji wobec Polski i rozumiał, że Petersburg nie może liczyć na poparcie Słowian, dopóki jeden $z$ narodów słowiańskich znajdujący się w granicach Imperium Rosyjskiego pozbawiony będzie możliwości niezależnego roz-

18 Pis'mo M.P. Pogodina K M.A. Maksimowiczu, Sankt-Peterburg 1882, s. 18.

19 M.P. P o g o d in, Istoriczeskie razmyszlenija ob otnoszenijach Rossii i Pol'szi k Rossii, [w:] i d e m, Istoriko-kriticzeskie otrywki, t. I, Moskwa 1846, s. 432-433. 
woju. Zrozumiał, że jeśli Rosja chce być postrzegana jako centralny ośrodek Słowiańszczyzny, wokół którego zjednocza się pokrewne jej narody, musi ona zmienić swój stosunek do Polaków i ich dążeń narodowościowych.

Zmusiło go to do zajęcia nowego stanowiska wobec Polski. Chociaż pozostał daleki od uznania niezawisłości narodu polskiego, zaproponował dopuszczenie rozwoju narodowości polskiej w ramach imperium. W odróżnieniu od ministra oświaty Uwarowa rosyjski historyk był przekonany, że poczucia narodowego nie da się zlikwidować i $z$ tego powodu występował przeciwko próbom rusyfikacji Polaków. Pogodin uważał, że zamiast gnębić polski nacjonalizm, dla władz petersburskich byłoby korzystniej realizować politykę protektoratu nad oświata w Polsce, oczywiście „przezornie i w granicach rozsadku, bez szkody dla interesów Rosji”20. Sądził, że można byłoby dokonać tego za pomoca wsparcia rozwoju kultury polskiej: języka, historii i literatury. Twierdził, że nie obrażając polskiego poczucia narodowego, przeciwnie: schlebiając mu, Rosjanie moga się $z$ Polakami doskonale porozumieć21.

Według Pogodina rząd powinien otoczyć opieką działalność polskich uczonych i literatów, pozwolić na nauczanie języka polskiego wspólnie $z$ rosyjskim, a nawet restytuować $w$ jakiejś formie Uniwersytet Warszawski, który zamknięto po powstaniu listopadowym. Szczególny nacisk kładł na nauczanie polskiej historii, której wówczas już nie wykładano. Wierzył, że historia Polski stanowi najwierniejsza sojuszniczkę władzy i może przynieść jej więcej pożytku niż kilka twierdz. Może bowiem sprawić, że Polacy pogodza się ze swoja obecną sytuacją, a nawet przekona ich o konieczności zjednoczenia Polski z Rosja. Jednocześnie rosyjski publicysta poczynił zastrzeżenie, że wykład polskiej historii musi być „obiektywny, prawdziwy", nie konkretyzujac, co miał na myśli. W Polsce należy również wykładać historię innych narodów słowiańskich, by za jej pomoca pokazać, ,jak od niepamiętnych czasów waśnie i brak zgody niszczyły i poddawały je pod okrutne jarzmo obcych, pod rządami których Słowianie nigdzie i nigdy nie byli szczęśliwi” 22 .

20 I d e m, Pis'mo $k$ ministru narodnogo prosweszczenija po powodu wozwraszczenii iż putiszestwija po Ewrope w 1839 g., [w:] i d e m, Soczinenija, t. IV, Moskwa 1874 , s. 34.

21 Ibidem, s. 28.

22 Ibidem, s. 32. 
W swych poglądach Pogodin kierował się interesem politycznym Rosji. Według niego kreowana $\mathrm{w}$ ten sposób polityka mogła mieć dobroczynny wpływ na pozostałe narody słowiańskie, które „patrza na Polskę jako na wzór rządów rosyjskich [kursywa M.P. Pogodina]"23. Protekcja nad polską narodowością i ustępstwa przed polskimi żądaniami narodowymi miały stanowić zagrywkę taktyczna, wynikająca $z$ chęci podtrzymywania wśród Słowian wyidealizowanego wizerunku Rosji. Celowały zatem w przyciągnięciu narodów słowiańskich do imperium. O motywach Pogodina świadczy jego pogląd na temat kierunku polityki, jaka winien realizować Petersburg na terytoriach, które znalazły się w granicach cesarstwa w wyniku rozbiorów Polski (czyli w Zachodniej Ukrainie, na Białorusi i Litwie). Według niego na ziemiach tych należy wykorzenić ducha polskiego. W tym celu proponował wykupienie ziem polskiego ziemiaństwa i zamiast niego sprowadzenie osadników $z$ terytoriów rosyjskich. Zachęcał do zwrócenia baczniejszej uwagi na sytuację chłopstwa, składającego się z Rosjan, jako przeciwwagi do właścicieli ziemskich, w przeważającej większości należących do szlachty polskiej. Jeżeli natomiast polityka mecenatu i liczenia się $z$ narodowa specyfika i charakterem Polaków zawiedzie, wówczas należy „za jednym zamachem rozsiedlić szlachtę po całym terytorium Rosji”24.

Obecność Polski w granicach cesarstwa czyniła szczególnie podatnymi na krytykę, rozprzestrzenione wśród części społeczeństwa rosyjskiego, panslawistyczne marzenia o wszechsłowiańskiej wspólnocie na czele $z$ Rosja. Pomysł utworzenia federacji narodów słowiańskich otrzymał nowy impuls w latach wojny krymskiej, która uznano za odpowiedni moment do jego realizacji. Człowiekiem, który go lansował, ponownie był Pogodin - oprócz innych powodów także dlatego, że widział w nim sposób, dzięki któremu Rosja mogła zyskać sojuszników i wygrać wojnę. Przyjęcie powyższego poglądu powtórnie zmusiło rosyjskiego historyka i publicystę do przewartościowania swojego stosunku do sprawy polskiej. Szukał bowiem rozwiąania, które pozwoliłoby jego ojczyźnie się uwolnić od dwuznacznej pozycji względem Polski i umożliwiło Rosji wypełnienie jej misji słowiańskiej. „Polska oddalała nas od całego słowiańskiego świata: Polska musi go do nas przyciągnąć" - napisał

23 Ibidem, s. 34.

${ }^{24}$ I d e m, Wtoroe donesenie Ministru narodnogo prosweszczenija o putiszestwii 1842 g., [w:] i d e m, Soczinenija, t. IV, s. 53, 64. 
w swoich „Historyczno-Politycznych Listach”, powstałych w czasie wojny 25 .

Pogodin uświadomił sobie, że jeśli Rosja pragnie, by wspólnota wszechsłowiańska miała przed sobą przyszłość, musi zrezygnować $z$ Polski. $Z$ tego powodu wzywał rządzących do restytucji państwa polskiego, rozumiejac pod tym samodzielne rzady zgodne $z$ polska historia, religia, charakterem i warunkami, ale $\mathrm{w}$ ramach imperium rosyjskiego i pod berłem cara. Wierzył, że ofiarując Polsce niepodległość, Rosja zyska w niej sojusznika. Wdzięczna za uzyskana wolność Polska wejdzie do wspólnoty słowiańskiej jako jej równoprawna członinki, a Słowianie „widząc naszą bezinteresowność, upewniwszy się o czystości naszych intencji, odrzuca wszystkie zachodnie oszczerstwa, uwolnią się $z$ wszelkich podejrzeń i wątpliwości i całkowicie oddadzą się Rosji, bezwarunkowo, z całej duszy, na śmierć i życie"26.

Pogodin należał do nielicznej grupy przedstawicieli społeczeństwa rosyjskiego, którzy w latach pięćdziesiątych XIX stulecia otwarcie opowiadali się za odnowieniem samodzielnych rządów w Polsce. Należy jednak podkreślić, że zaproponowana przez niego zmiana oficjalnej linii politycznej Petersburga nie wynikała $z$ chęci naprawienia historycznej niesprawiedliwości względem Polaków. Zgodnie $z$ planami Pogodina zmiana w polityce carskiej wobec Polski miała stanowić część większego zwrotu, który powinien nastąpić w stosunku dyplomacji rosyjskiej wobec słowiańskich ruchów narodowych, w Imperium Austriackim i na Bałkanach. Według niego Rosja powinna zrezygnować $z$ sojuszu $z$ Prusami i Austria i w swojej polityce zagranicznej oprzeć się przede wszystkim na narodach słowiańskich. Tylko w tym kontekście historyk rosyjski dopuszczał możliwość samodzielnych rządów polskich. Chodziło więc o czysto taktyczne posunięcie, które zgodnie ze słowami Pogodina pozwoliłoby Rosji wypełnić swoja misję słowiańska, stając na czele narodowowyzwoleńczego ruchu narodów słowiańskich. W konkretnym momencie historycznym miało ono zapewnić Rosji sukces w prowadzonej wojnie.

Gdy Polska otrzyma własny rząd, „o czym piękniejszym będa mogli marzyć austriaccy i tureccy Słowianie? Będą nasi, to znaczy stana się członkami przyszłego wielkiego związku wschodniego".

25 Pol'skij wopros. Sobranie rassużdenii, zapisok i zamecznii M.P. Pogodina 1831-1867 gg., Moskwa 1867, s. 54.

26 Pis'mo o Pol'sze (w naczale Krymskoj wojny), [w:] ibidem, s. 37. 
Majac przed oczami przykład Polski, narody słowiańskie zapragna dla siebie tej samej wolności i jeden po drugim przyłączą się do Rosji, „i w ten sposób będzie nas sto milionów. Zapraszamy do boju" 27.

Historyczno-polityczna koncepcja Pogodina stanowi doskonały przykład dwuznacznej postawy Rosji i zderzenia między kwestia polska, jako wewnętrznym problemem cesarstwa, $z$ zewnętrznym dylematem politycznym dotyczacym wsparcia ruchu wyzwolenia Słowian.

Natomiast na pierwszy rzut oka dylemat ten nie był taki ważny dla słowianofilów moskiewskich - nielicznej, lecz wpływowej grupy w społeczeństwie rosyjskim, która także zaadaptowała ideę o sławnej przyszłości Słowian i znaczeniu narodu rosyjskiego jako najwybitniejszego przedstawiciela słowiańskiego odrodzenia. Było tak, gdyż ich poglądy pozbawione były niuansów politycznych. Mówiąc o wspólnocie słowiańskiej, mieli na myśli integrację Słowian w ramach jednego kręgu kulturowego. Słowianofile postrzegali ten zwiazek w kategoriach zbliżenia duchowo-religijnego i kulturalno-oświatowego i wyraźnie podkreślali, że nie wspierają planów politycznego zjednoczenia narodów słowiańskich. Koncepcja słowianofilska nie dopuszczała wsparcia poglądów panslawistycznych, ponieważ według jej zwolenników wspólny organizm polityczny uniemożliwiałby samodzielny rozwój poszczególnych nacji słowiańskich $^{28}$.

Już w pierwszym numerze słowianofilskiego czasopisma „Russkaja beseda” z 1856 r. w kwestii możliwości utworzenia wspólnego państwa słowiańskiego redakcja opublikowała następujacy komentarz: „Sztandarem Rosji powinien być nie panslawizm $\mathrm{w}$ znaczeniu politycznym, nie centralizacja, lecz uznanie praw każdej narodowości do samodzielnego, oryginalnego istnienia, którego obrona i ochrona niewatpliwie obarczona byłaby Rosja" 29 .

Słowianofile przeciwstawiali chyląca się ku upadkowi cywilizację romańsko-germańska Wschodowi, światu słowiańskiemu, który dopiero wypełni swoją misję historyczną. Decydującą różnicą mię-

27 Zapiska o Pol'sze (1856), [w:] ibidem, s. 55-56.

$28 \mathrm{Na}$ ten temat A.S. Chomjakow, Polnoe sobranie soczinenii, t. VIII (Pis'ma), Moskwa 1904, s. 73, 100; J.F. S a m a r i n, Soczinenija, t. VI, Jezuity $i$ stat'i bogoslowsko-filosofskogo soderżanija, Moskwa 1887, s. 240; N.I. C i mb a e w, Slawjanofil'stwo, Moskwa 1986, s. 31.

29 „Russkaja beseda” 1856, z. 1, s. 61. 
dzy oboma tymi światami była dla nich religia, postrzegana jako nośnik duchowego zaczynu w każdym narodzie. Przeciwstawienie Wschód-Zachód bazowało na różnicy konfesyjnej - poczynione było na linii prawosławie-katolicyzm. $Z$ tego też powodu w środowisku słowianofilskim mówiło się o świecie łacińsko-katolickim i słowiańsko-prawosławnym. Dla ludzi $z$ tego kręgu prawdziwa, pierwotna religia Słowian było prawosławie. Słowianofile wierzyli w nierozerwalny związek między prawosławiem i Słowiańszczyzną. Według Jurija Fiodorowicza Samarina ,jedynie w prawosławiu naród słowiański oddycha i porusza się swobodnie, a poza nim nieuchronnie popada w niewolę i ulega deformacji u podstaw swojego bytu"30.

Zgodnie $z$ koncepcją słowianofilską rezygnujac $z$ prawosławia, Słowianie zadali ciężki cios swojej oryginalności, zanieczyścili swoją nację i zniszczyli jej integralność, zmienili swój charakter narodowy. Innymi słowy, zlikwidowali to wszystko, co zapewniało im szczególne miejsce w dziejach. „W chwili obecnej ani Polak-katolik, ani Czech-katolik, ani też Morawianin-protestant nie wyrazi oryginalnej myśli słowiańskiej. Wiara, jedynie wiara może zebrać odłamki i stworzyć $z$ nich coś organicznego. Która wiara? Nie katolicyzm, nie protestantyzm, lecz jedynie nasze prawosławie. Bez prawosławia nasza nacja jest niczym. $Z$ prawosławiem nasza nacja ma światowe znaczenie" - pisał Aleksander Iwanowicz Koszelew do Iwana Sergiejewicza Aksakowa w liście z 15 października 1858 r. ${ }^{31}$

Przekonanie o wyższości wiary ortodoksyjnej ograniczało słowianofilskie poglądy na temat jedności Słowian do ram prawosławia, a mesjańska rolę Słowiańszczyzny wyłącznie do jej prawosławnej części. W ten sposób wyłączano Słowian-katolików z kręgu Bożych pomazańców, czyniąc $z$ nich, w oczach słowianofilów, ludzi drugiej kategorii, „na poły Słowian”32. Dlatego też nadzieje słowianofilów zwiazane były jedynie $z$ prawosławnymi Słowianami, do środowiska których nie przeniknęły pokusy Zachodu. Nie wiązali oni większych nadziei $z$ tą częścią Słowiańszczyzny, która została zanieczyszczona zachodnimi wpływami i nauczaniem Kościoła katolickiego. $Z$ tych powodów słowianofile unikali wymieniania Polski

30 J.F. S a m a ri n, op. cit., t. I, Stat'i raznorodnogo soderżanija i po pol'skomu woprosu, Moskwa 1877, s. 248.

31 N.P. Kolju pa now, Biografija Aleksandra Iwanowicza Koszelewa, t. II, Moskwa 1892, s. 250-251.

32 O ile wśród słowianofilów funkcjonowały uprzedzenia, miały one podłoże religijne, nie zaś narodowe. 
wśród członków rodziny narodów słowiańskich, gdyż tam katolicki żywioł zakorzenił się najmocniej i znalazł najbardziej oddanych zwolenników.

Informacje o poglądach słowianofilów moskiewskich na sprawę politycznej przyszłości Słowiańszczyzny, w szczególności zaś Polski, sa ułamkowe, lecz nawet ich niewielka liczba wskazuje, że podejmowali oni kwestię polska. Podobnie jak u konserwatywnych nacjonalistów pokroju Pogodina także wśród nich widoczne jest dążenie do pogodzenia ich poglądów na kwestię słowiańską $z$ interesami Rosji względem Polski. W tej sprawie szczególnie wymowny jest list jednego $z$ wiodacych słowianofilow - Aleksieja Stiepanowicza Chomiakowa, napisany w 1848 r., w którym rozmyślał on nad polityczną przyszłością narodów słowiańskich, w tym Polaków. Chomiakow wspierał restytuowanie niepodległości Polski w następujących granicach: Poznań i Gdańsk, Galicja z Krakowem, Księstwo Warszawskie i ta część Litwy, w której nie mówi się po rosyjsku. Proces ten jednak, według niego, nie mógł być dziełem rządu bąź administracji państwowej, lecz dokonaniem narodu. $Z$ tego też powodu bronił idei samookreślenia się nacji: powszechne referendum powinno rozstrzygnać losy każdego $z$ narodów słowiańskich, ale winno się ono odbyć zarówno na ziemiach polskich, jak i na terytoriach zamieszkałych przez Słowian, a znajdujących się w obrębie państwa Habsburgów.

Chomiakow akcentował czysto polityczną korzyść, jaką Rosja uzyskałaby takim posunięciem: ogólnodostępne prawo do głosowania zniszczyłoby wpływy arystokracji i mieszczaństwa w Polsce. Prócz tego „wśród chłopstwa byłoby wiele głosów na naszą korzyść, a w Galicji większość (ze względu na pokrewieństwo językowe, a szczególnie bliskość duchowa) opowiedziałaby się za nami lub, $\mathrm{w}$ ostateczności, za odrębnym funkcjonowaniem i w ten sposób sama Polska byłaby zdezorganizowana na zawsze". Na Litwie, jego zdaniem, rezultat byłby zbliżony 33 .

Autor ten uważał powierzenie narodom słowiańskim prawa do niezależnego kreowania swojej przyszłości politycznej za środek, dzięki któremu Rosja pozyska ich przychylność, jak również za narzędzie służące do zlikwidowania polskich pretensji wobec terytoriów, na których przeważająca ludnością byli prawosławni, a które rosyjskie społeczeństwo uznawało za rdzennie swoje.

33 A.S. C ho mjakow, op. cit., s. 397. 
Taka postawa dowodzi, że nawet ludzie pozbawieni nacjonalistycznych uczuć, jakimi byli słowianofile, nie uniknęli dylematu, w jaki sposób pogodzić swoje wyobrażenia o wspólnocie słowiańskiej i misji Rosji wśród Słowian $z$ rosyjskimi interesami politycznymi w Polsce. Znamienny jest fakt, że to powstanie styczniowe i różnice zdań w gronie słowianofilów na temat tego, jaka powinna być polityka Petersburga wobec Polski, stały się jedną z głównych przyczyn, które doprowadziły do rozdarcia wewnatrz ich społeczności.

Mimo tego, że idea jedności słowiańskiej i Rosji jako centrum odradzającej się Słowiańszczyzny utorowała sobie drogę w społeczeństwie rosyjskim, nie zyskała w nim dostatecznego wsparcia do dalszego rozwoju. Polska okazała się tym kamieniem obrazy, który w pierwszej połowie XIX w. uniemożliwił rosyjskim rządzącym eksploatacje tej idei, a wykształconej elicie rosyjskiej okazanie jej pełnego poparcia. $Z$ tego powodu oficjalne władze w Petersburgu zrezygnowały $z$ włączenia idei o misji Rosji wśród Słowian do arsenału wykorzystywanych przez siebie środków ideologicznych. Gdy mówiono o jedności słowiańskiej, nacisk kładziono na współpracę w dziedzinie kultury, pokrewieństwo języka i tradycji, unikając najmniejszej nawet wzmianki na temat wspólnoty politycznej. O ile więc państwo i społeczeństwo rosyjskie deklarowały poparcie dla słowiańskich ruchów narodowościowych, o tyle od połowy stulecia ograniczały to wsparcie jedynie do narodów chrześcijańskich przebywających w granicach Imperium Osmańskiego.

Z języka bułgarskiego przełożył KIRIŁ MARINOW*

* Uniwersytet Łódzki, Wydział Filozoficzno-Historyczny, Instytut Historii, Katedra Historii Bizancjum. 